\title{
Short communication: Jersey $\times$ Holstein crossbreds compared with pure Holsteins for body weight, body condition score, fertility, and survival during the first three lactations
}

\author{
B. J. Heins, L. B. Hansen, A. R. Hazel, A. J. Seykora, D. G. Johnson, and J. G. Linn \\ Department of Animal Science, University of Minnesota, St. Paul 55108
}

\begin{abstract}
Crossbred cows $(n=80)$ resulting from the use of Jersey (JE) semen on their pure Holstein (HO) dams were compared with pure HO cows $(\mathrm{n}=77)$ for body weight, body condition score, fertility, and survival during their first 3 lactations. Cows were in 2 research herds of the University of Minnesota and calved from September 2003 to June 2008. The JE $\times$ HO crossbred cows had significantly less body weight during the first $(-56 \mathrm{~kg})$, second $(-67 \mathrm{~kg})$, and third $(-82 \mathrm{~kg})$ lactations than pure $\mathrm{HO}$ cows. However, JE $\times$ HO cows had significantly greater body condition score during the first (2.94 vs. 2.84), second (2.97 vs. 2.84), and third (2.99 vs. 2.87 ) lactations than pure HO cows. For fertility, JE $\times$ HO cows had fewer days to first breeding during the first $(-10.6 \mathrm{~d})$, second $(-8.4 \mathrm{~d})$, and third $(-12.3 \mathrm{~d})$ lactations than pure HO cows. Crossbred cows were not significantly different from pure HO cows for number of services during first lactation; however, JE $\times$ HO cows had significantly fewer services (2.2) than pure HO cows (2.7) during the second lactation. Also, $\mathrm{JE} \times \mathrm{HO}$ cows had significantly fewer days open than pure HO cows in the first $(-24 \mathrm{~d})$, second $(-42 \mathrm{~d})$, and third $(-42 \mathrm{~d})$ lactations. For survival, JE $\times \mathrm{HO}$ cows were not significantly different from pure HO cows for percentage of cows calving a second time; however, a tendency existed for a higher percentage of $\mathrm{JE} \times \mathrm{HO}$ cows $(63.8 \%)$ than pure HO cows $(49.4 \%)$ to calve a third time, and a higher percentage of $\mathrm{JE} \times \mathrm{HO}$ cows calved a third time within 28,34 , and $40 \mathrm{mo}$ of first calving than pure $\mathrm{HO}$ cows.
\end{abstract}

Key words: crossbreeding, Jersey, body condition, fertility

\section{Short Communication}

Fertility has decreased for Holstein (HO) cows globally, and selection for milk production has likely con-

Received October 21, 2011.

Accepted March 7, 2012.

${ }^{1}$ Corresponding author: hein0106@umn.edu tributed to increases in the number of services (NoS) and to greater days open (DO) of pure HO cows (Oseni et al., 2003). The antagonism of milk production and cow fertility is well documented, and research has reported substantial genetic correlation (0.30 to 0.35) between milk production and DO (VanRaden et al., 2004). The decrease in fertility and survival of pure $\mathrm{HO}$ cows over time around the world has resulted in increased interest in crossbreeding of dairy cattle. In a survey by Weigel and Barlass (2003), dairy producers indicated that crossbreeding improved fertility and survival of dairy cows. During recent years, milk pricing in most markets has placed greater emphasis on the solids in milk rather than fluid, which resulted in the $\mathrm{HO}$ breed having less of a competitive advantage compared with other breeds.

Jersey $(\mathbf{J E}) \times \mathrm{HO}$ crossbred cows in some countries have advantages over pure $\mathrm{HO}$ cows for profitable dairying. In Australia, JE $\times \mathrm{HO}$ cows had $40 \mathrm{~kg}$ less BW than did pure HO cows; however, they had greater BCS and higher first-service conception rates than did pure HO cows (Auldist et al., 2007). Also, Prendiville et al. (2009) reported mean BW was $50 \mathrm{~kg}$ less, but $\mathrm{BCS}$ was higher for $\mathrm{JE} \times \mathrm{HO}$ cows compared with pure $\mathrm{HO}$ cows in Ireland. In 2 other Irish studies, JE $\times \mathrm{HO}$ cows had lower BW, but greater BCS compared with pure HO cows (Prendiville et al., 2010, 2011). In New Zealand, JE $\times$ HO cows had lower BW and greater survival through their lifetime than did pure HO cows (Lopez-Villalobos et al., 2000). The JE $\times$ HO cows had significantly higher conception rates than did pure $\mathrm{HO}$ cows in Germany, although the 2 groups did not differ for survival during first lactation (Freyer et al., 2008).

Two research herds at the University of Minnesota shared a crossbreeding design beginning in 2000. The research dairy on the St. Paul campus of the University of Minnesota has 90 tie-stalls and a 40-head compost barn, and the West Central Research and Outreach Center in Morris, Minnesota, has a 150-head, low-input grazing system. The design of the experiment and a detailed description of heifers born, raised, and number of cows calving a first time were thoroughly described in Heins et al. $(2008,2011)$. The genetic level of sires of 
cows and the number of daughters per sire are reported in Heins et al. (2008). All AI bulls had PTA greater than the 90th percentile for the Net Merit index of the United States within breed at the time of selection, and bulls had predominately North American ancestry.

Both herds (St. Paul and Morris) calve seasonally, and all virgin heifers for both locations were reared and mated at Morris. Cows at St. Paul are bred with the aid of synchronization hormones mostly during the winter (January to March), and cows and heifers at Morris are bred during the winter (January to March) and summer (June to August), first by observation and with the aid of synchronization hormones for cows not observed in heat. Cows in St. Paul calved mostly in the fall, and in the Morris herd cows calved mostly in the spring. Season of calving was spring (March to July) or fall (September to February). Seasons containing less than 5 calvings for each breed group were combined (fall season with following spring season) at Morris. Cows calved for the first time from September 2003 to May 2005. Data for later lactations was collected on the same cows through September 2008.

The BW was recorded on cows using a digital scale as cows exited the milking parlor approximately once per month during lactations, and BCS was measured at the same time as $\mathrm{BW}$ on a 1 to 5 scale in increments of 0.25 , with $1=$ excessively thin, and $5=$ excessively fat (Wildman et al., 1982). Neither BW nor $\mathrm{BCS}$ has been routinely reported for $\mathrm{JE} \times \mathrm{HO}$ cows versus pure $\mathrm{HO}$ cows in the United States. The BW and BCS were analyzed for 45-d intervals postpartum $(1$ to $45 \mathrm{~d}, 46$ to $90 \mathrm{~d}, 91$ to $135 \mathrm{~d}, 136$ to $180 \mathrm{~d}, 181$ to $225 \mathrm{~d}, 226$ to $270 \mathrm{~d}$, and 271 to $315 \mathrm{~d}$ ) up to $315 \mathrm{~d}$, and independent variables for statistical analysis were effects of herd, year-season of calving nested within herd, breed group, parity nested within breed group, and 45-d period nested within parity and breed group. The MIXED procedure of SAS (SAS Institute, 2008) was used, with cow nested within breed group as a random variable with repeated measures. The autoregressive covariance $\mathrm{AR}(1)$ structure was used, and the lowest Akaike information criterion (Littell et al., 1998) resulted. Preliminary analysis for both BW and BCS indicated that interaction of herd and breed group was not significant, so the interaction effect was removed from the model. Parity nested within breed group and 45-d period nested within parity and breed group were included in the statistical model because of the potential for different rates of maturity of the breed groups and, consequently, potentially different shapes of the curves of BW and BCS for breed groups.

Days to first breeding (DFB) was the date of first service minus the calving date, and NoS was the total number of services recorded during lactations with a maximum of 6 services. Only $1 \mathrm{JE} \times \mathrm{HO}$ cow and 4 pure HO cows exceeded the maximum of 6 services. The NoS was recorded for the duration of the lactation and was limited to 6 services to avoid an exaggerated increase in variance because of the small number of cows with NoS beyond 6 . The DO of cows was measured as actual DO with pregnancy status confirmed by ultrasound and reconfirmed, when possible, with a subsequent date of calving. To be included in the analysis for DO, cows were required to have at least 250 DIM, which is the requirement in the United States for cows to be included in genetic evaluation for DO (VanRaden et al., 2004). Unadjusted DO ranged from 46 to 610 d; however, cows with more than $250 \mathrm{~d}$ for DO had DO set to $250 \mathrm{~d}$. Seventeen percent of JE $\times$ HO cows and $31 \%$ of pure HO cows had DO greater than $250 \mathrm{~d}$.

For statistical analysis of DFB, NoS, and DO, independent variables were effects of herd, year-season of calving nested within herd, breed group, and parity nested within breed group. The MIXED procedure of SAS (SAS Institute, 2008) was used with cow nested within breed group as a random variable to obtain solutions and conduct the ANOVA. Preliminary analysis for DFB, NoS, and DO indicated that interaction of herd and breed group was not significant, so the interaction effect was removed from the model.

The JE $\times \mathrm{HO}$ and pure $\mathrm{HO}$ cows were also compared for pregnancy rate (PR), which measured the proportion of cows that became pregnant during each 21-d estrus cycle. The PR required cows to have at least 1 breeding and greater DIM than the voluntary waiting period of each herd. The method of de Vries et al. (2005) was used to calculate PR, and the LIFETEST procedure of SAS (SAS Institute, 2008) was used for analysis of PR. The NoS and PR were not analyzed for third-lactation cows, because $7 \mathrm{JE} \times \mathrm{HO}$ and 2 pure HO cows that calved a third time were sold within 10 $\mathrm{d}$ of first breeding for dairy purposes at Morris. Potentially, culling or herd management biases, or both, may have contributed to the higher percentage of JE $\times \mathrm{HO}$ cows sold; however, all 9 of the cows calved 3 times and were sold to reduce the size of the herd to facilitate other research studies.

For survival, JE $\times \mathrm{HO}$ and pure $\mathrm{HO}$ cows were compared for percentage of cows calving a second and third time, and all cows in this study had the opportunity to calve 3 times. Survival to second and third calving was recorded in a binary manner as calved a second or third time (1) or did not calve a second or third time (0). Additionally, $\mathrm{JE} \times \mathrm{HO}$ and pure $\mathrm{HO}$ cows were compared for 3 thresholds for calving interval $(14 \mathrm{~m}, 17 \mathrm{~m}$, and $20 \mathrm{mo}$ ) from first to second calving and from second to third calving. Furthermore, JE $\times \mathrm{HO}$ and pure $\mathrm{HO}$ cows were compared for 3 thresholds of calving interval 
Table 1. Least squares means for BW during the first 3 lactations for pure Holstein and Jersey $\times$ Holstein crossbred cows $^{1}$

\begin{tabular}{|c|c|c|c|c|c|c|c|c|c|c|c|c|}
\hline $\begin{array}{l}\text { Measurement } \\
\text { for } 45-\mathrm{d} \\
\text { period }(\mathrm{kg})\end{array}$ & \multicolumn{4}{|c|}{ First lactation } & \multicolumn{4}{|c|}{ Second lactation } & \multicolumn{4}{|c|}{ Third lactation } \\
\hline 1 & 522.1 & 8.9 & $-56.2^{* *}$ & 8.9 & 566.9 & 6.3 & $-59.9^{* *}$ & 6.2 & 604.0 & 8.5 & $-75.6^{* *}$ & 8.0 \\
\hline 5 & 531.1 & 9.2 & $-62.8^{* *}$ & 9.1 & 591.9 & 6.5 & $-69.3^{* *}$ & 6.4 & 628.9 & 9.0 & $-85.8^{* *}$ & 8.6 \\
\hline 6 & 541.2 & 9.4 & $-60.2^{* *}$ & 9.3 & 598.1 & 6.7 & $-67.2^{* *}$ & 6.5 & 634.2 & 9.1 & $-84.8^{* *}$ & 8.8 \\
\hline 7 & 560.1 & 9.6 & $-57.1^{* *}$ & 9.4 & 615.4 & 6.8 & $-60.2^{* *}$ & 6.7 & 655.7 & 9.6 & $-77.5^{* *}$ & 9.1 \\
\hline Mean of periods & 523.9 & 8.6 & $-56.4^{* *}$ & 8.6 & 582.7 & 5.7 & $-67.0^{* *}$ & 5.6 & 619.2 & 7.8 & $-81.8^{* *}$ & 7.5 \\
\hline
\end{tabular}

${ }^{1}$ Least squares means for Jersey $\times$ Holstein crossbred cows are expressed as a difference from pure Holsteins.

$* * P<0.01$ for difference from pure Holsteins.

$(28,34$, and $40 \mathrm{mo})$ from first to third calving. For all of the survival traits, a $\chi^{2}$ test (SAS Institute, 2008) was conducted to evaluate breed group differences.

Table 1 reviews the BW for individual 45-d periods and for lactations (mean of the 45-d periods) for the $\mathrm{JE} \times \mathrm{HO}$ and pure $\mathrm{HO}$ cows. For lactations, the JE $\times$ HO cows had significantly $(P<0.01)$ lower BW than did pure HO cows during first (468 vs. $524 \mathrm{~kg}$ ), second $(516$ vs. $583 \mathrm{~kg}$ ), and third (537 vs. $619 \mathrm{~kg}$ ) lactations.

Within each of the 45-d periods, JE $\times \mathrm{HO}$ cows had significantly $(P<0.01)$ lower BW than did pure $\mathrm{HO}$ cows (Table 1) during all 3 lactations, and the difference of the $\mathrm{BW}$ of $\mathrm{JE} \times \mathrm{HO}$ cows compared with pure $\mathrm{HO}$ cows ranged from 51 to $63 \mathrm{~kg}$ during the first, 60 to $74 \mathrm{~kg}$ during the second, and 76 to $86 \mathrm{~kg}$ during the third lactations. The BW change was similar for JE $\times \mathrm{HO}$ to that of pure $\mathrm{HO}$ cows from the beginning to the end of the first $(+37.1$ vs. $+38.0 \mathrm{~kg}$, respectively), second ( +48.2 vs. $+48.5 \mathrm{~kg}$, respectively), and third
(+49.8 vs. $+51.7 \mathrm{~kg}$, respectively) lactations. The BW decreased slightly at the beginning of each lactation and then increased steadily for both $\mathrm{JE} \times \mathrm{HO}$ and pure $\mathrm{HO}$ cows through the seventh period. Results for BW change across 305-d lactations were consistent with the results of Prendiville et al. (2009), who also reported that $\mathrm{JE} \times \mathrm{HO}$ cows and pure $\mathrm{HO}$ cows had similar BW change.

Results for BCS for individual 45-d periods and across lactations (mean of the 45-d periods) are shown in Table 2. Both $\mathrm{JE} \times \mathrm{HO}$ and pure $\mathrm{HO}$ cows decreased in BCS at the beginning of all 3 lactations, and this suggests that cows were mobilizing body fat to meet the demands of production (Roche et al., 2009). For lactations (mean of the 45-d periods), JE $\times$ HO cows had significantly $(P<0.01)$ greater BCS than did pure HO cows throughout first (2.94 vs. 2.84, respectively), second (2.97 vs. 2.84, respectively), and third (2.99 vs. 2.87 , respectively) lactations.

Table 2. Least squares means for BCS during the first 3 lactations for pure Holstein and Jersey $\times$ Holstein crossbred cows ${ }^{1}$

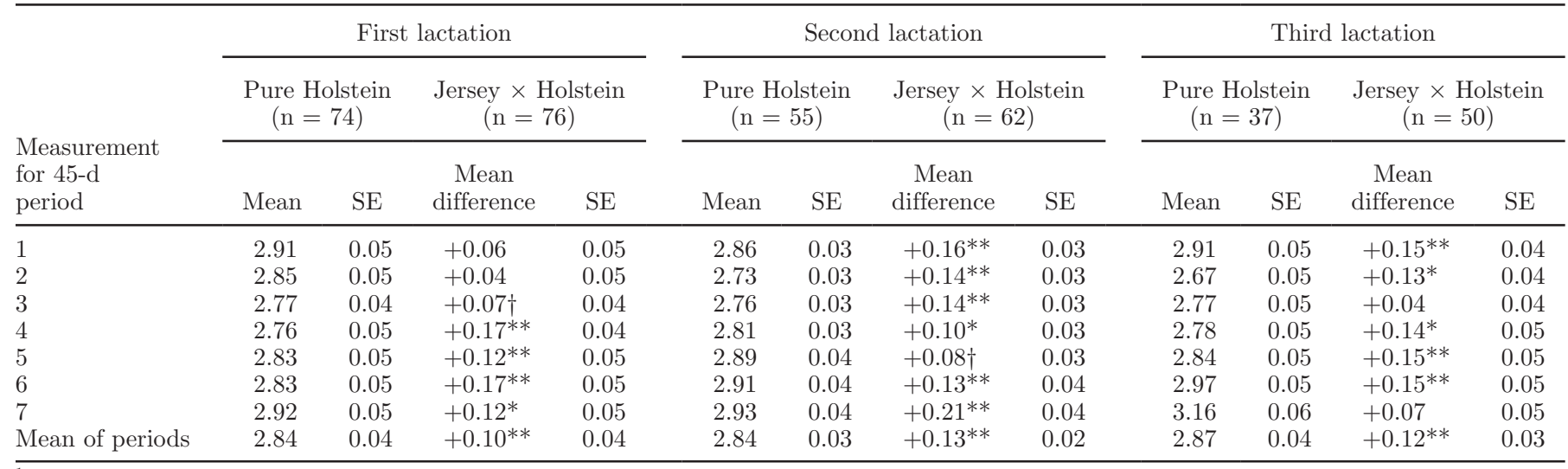

${ }^{1}$ Least squares means for Jersey $\times$ Holstein crossbred cows are expressed as a difference from pure Holsteins.

${ }^{*} P<0.05$ for difference from pure Holsteins; ${ }^{* *} P<0.01$ for difference from pure Holsteins; $\uparrow P<0.10$ for difference from pure Holsteins. 
Within each 45-d period during first lactation, JE $\times$ HO cows had significantly $(P<0.05)$ greater BCS than did pure $\mathrm{HO}$ cows at periods $4,5,6$, and 7 , with a tendency $(P<0.10)$ for crossbred cows to have higher BCS than pure HO cows for period 3. The breed groups did not differ for BCS in period 1 or 2 during first lactation. During second lactation, JE $\times \mathrm{HO}$ cows had significantly $(P<0.05)$ greater BCS than did pure HO cows for all 45-d periods except 5 , and crossbred cows had significantly $(P<0.05)$ greater BCS than did pure HO cows for all 45-d periods except 3 and 7 during third lactation. The advantage of $\mathrm{JE} \times \mathrm{HO}$ cows compared with pure HO cows for BCS for 45-d periods ranged from +0.04 to +0.17 during first lactation, +0.08 to +0.21 during second lactation, and +0.04 to +0.15 during third lactation.

The JE $\times$ HO cows had significantly $(P<0.01)$ fewer DFB during first lactation (79.4 vs. $90.0 \mathrm{~d}$, respectively), second lactation (77.7 vs. 86.1 d, respectively), and third lactation (64.4 vs. $76.7 \mathrm{~d}$, respectively) than did pure HO cows (Table 3). The DFB of pure HO cows in this study was similar to those of Midwestern herds ( $87 \mathrm{~d}$ ) reported by Norman et al. (2009), and the weighted mean PR of the pure HO cows (12.4\%) was similar to the Minnesota DHIA average of $12.8 \%$ (Minnesota DHIA, 2007). For NoS, the JE $\times \mathrm{HO}$ and pure $\mathrm{HO}$ cows did not differ during first lactation, but the crossbred cows had significantly $(P<0.05)$ fewer NoS (2.2 vs. 2.7 ) than did pure $\mathrm{HO}$ cows during second lactation. The $\mathrm{JE} \times \mathrm{HO}$ cows had significantly $(P<$ $0.05)$ higher PR (20.3 vs. $12.3 \%)$ during first lactation and significantly $(P<0.01)$ higher PR $(24.5$ vs. $13.3 \%)$ during second lactation than did pure HO cows. Crossbred cows had significantly $(P<0.05)$ fewer DO than the pure HO cows during first lactation (124 vs. 148 d), second lactation (121 vs. $163 \mathrm{~d}$ ), and third lactation $(158$ vs. 200 d). For genetic evaluations in the United States, 1 percentage unit of $\mathrm{PR}$ is equal to $4 \mathrm{DO}$ for calculation of PTA (VanRaden et al., 2004). The 24-d (first lactation) and 42-d (second and third lactation) difference for DO between breed groups in this study corresponds to a 6 and $11 \%$ difference of PTA for PR, respectively, which is similar to the 8 and $11 \%$ actual difference for PR observed in this study.

For survival from first to second calving (Table 4), $\mathrm{JE} \times \mathrm{HO}(80 \%)$ and pure $\mathrm{HO}(71 \%)$ cows did not differ significantly $(P=0.21)$; however, a higher percentage of $\mathrm{JE} \times \mathrm{HO}$ cows than pure $\mathrm{HO}$ cows tended $(P<$ $0.10)$ to calve a third time ( 64 vs. $49 \%$ ). For the interval from first to second calving, a higher percentage of JE $\times$ HO than pure HO cows tended $(P<0.10)$ to calve a second time within 14 mo of first calving (61 vs. $48 \%$ ). A significantly $(P<0.05)$ higher percentage of JE $\times$ $\mathrm{HO}$ than pure $\mathrm{HO}$ cows calved a third time within 28

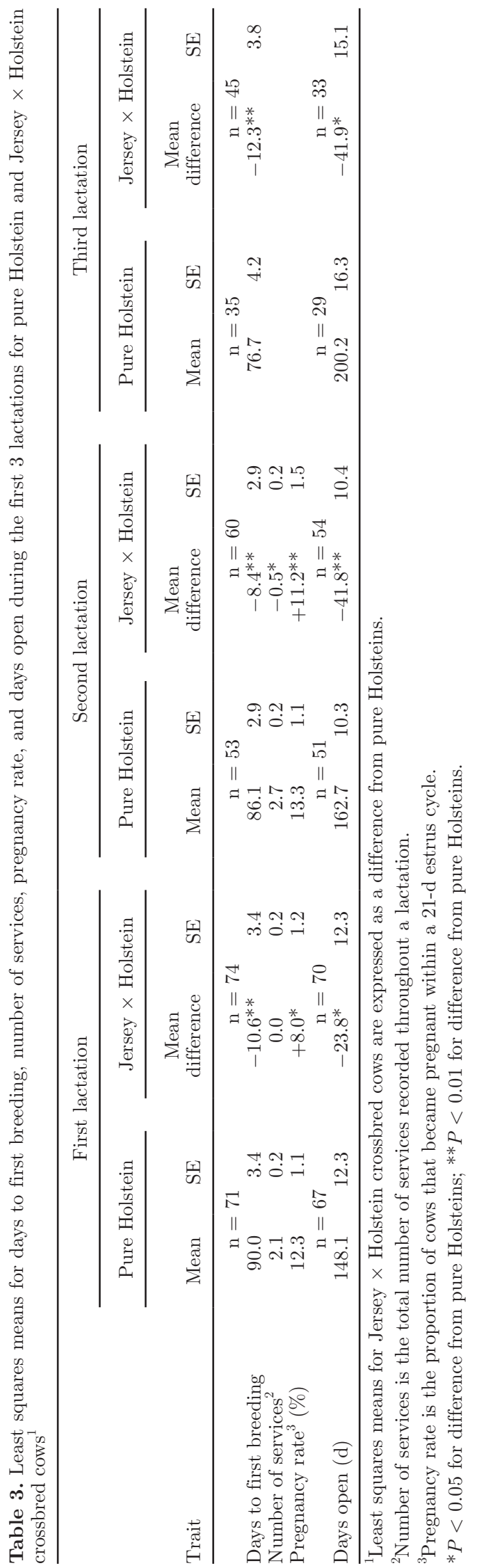

Journal of Dairy Science Vol. 95 No. 7, 2012 
Table 4. Survival of pure Holstein and Jersey $\times$ Holstein crossbred cows

\begin{tabular}{lcc}
\hline Item & Pure Holstein & Jersey $\times$ Holstein $^{1}$ \\
\hline Survival to subsequent calving (\%) & $\mathrm{n}=77$ & $\mathrm{n}=80$ \\
Calved a second time & 71.4 & +8.6 \\
Calved a third time & 49.4 & $+14.4 \dagger$ \\
Interval from first to second calving (\%) & $\mathrm{n}=77$ & $\mathrm{n}=80$ \\
$14 \mathrm{mo}$ & 48.1 & $+13.2 \dagger$ \\
$17 \mathrm{mo}$ & 57.1 & +11.7 \\
$20 \mathrm{mo}$ & 68.8 & +10.0 \\
Interval from first to third calving (\%) & $\mathrm{n}=77$ & $\mathrm{n}=80$ \\
28 mo & 26.0 & $+21.5^{* *}$ \\
$34 \mathrm{mo}$ & 42.9 & $+18.4^{*}$ \\
40 mo & 49.4 & $+14.4 \dagger$ \\
Interval from second to third calving (\%) & $\mathrm{n}=55$ & $\mathrm{n}=64$ \\
$14 \mathrm{mo}$ & 40.0 & $+24.1^{*}$ \\
17 mo & 56.4 & +13.9 \\
20 mo & 69.1 & +9.0 \\
\hline
\end{tabular}

${ }^{1}$ Jersey $\times$ Holstein crossbred cows are expressed as a difference from pure Holsteins.

${ }^{*} P<0.05$ for difference from pure Holsteins; ${ }^{* *} P<0.01$ for difference from pure Holsteins; $\dagger P<0.10$ for difference from pure Holsteins.

mo (48 vs. $26 \%)$ and 34 mo (61 vs. $43 \%$ ) from first calving, and a higher percentage of $\mathrm{JE} \times \mathrm{HO}$ than pure HO cows tended $(P<0.10)$ to calve a third time within 40 mo (64 vs. $49 \%)$ from first calving. For the interval from second to third calving, a significantly $(P<0.05)$ higher percentage of crossbred cows calved a third time within 14 mo of second calving than pure HO cows (64 vs. $40 \%$ ). The survival of the pure HO cows to second and third calving in this study is similar to the survival for $\mathrm{HO}$ cows in the United States reported by Hare et al. (2006) of $73 \%$ to second calving and $45 \%$ to third calving.

Potentially, $\mathrm{JE} \times \mathrm{HO}$ cows in this study devoted more of the energy they consumed to maintain and restore BCS compared with pure $\mathrm{HO}$ cows and this, in turn, may have resulted in the enhanced fertility of the crossbred cows compared with pure $\mathrm{HO}$ cows. The fertility advantages of the $\mathrm{JE} \times \mathrm{HO}$ compared with pure HO cows likely was a major contributor to their enhanced survival. The superiority of crossbred cows for fertility and survival compared with pure $\mathrm{HO}$ cows resulted in cows calving more frequently during longer lifetimes and, consequently, a generation of more female offspring to improve the overall efficiency of milk production.

Heins et al. (2011) earlier reported the shortcomings of the $\mathrm{JE} \times \mathrm{HO}$ compared with the pure $\mathrm{HO}$ cows in this study with regard to decreased production of fat plus protein during second and third lactation, a higher frequency of cows culled for udder conformation, and higher mean SCS during third lactation. On the other hand, the results of the present study indicate the $\mathrm{JE} \times \mathrm{HO}$ cows had major advantages over pure HO for fertility and survival. The advantages and disadvantages of $\mathrm{JE} \times \mathrm{HO}$ compared with pure $\mathrm{HO}$ cows may depend greatly on environmental conditions. For example, for herds with high production levels, the proportionately larger udders in relation to body size of $\mathrm{JE} \times \mathrm{HO}$ compared with pure $\mathrm{HO}$ cows may be of great concern. However, in herds with lower levels of production, especially in the Southern Hemisphere, the concerns about udder depth may be less pronounced. Consequently, fertility and survival must be considered alongside production, feed consumption, udder conformation, and udder health to conduct an overall economic evaluation of $\mathrm{JE} \times \mathrm{HO}$ compared with pure $\mathrm{HO}$ cows for commercial milk production.

\section{ACKNOWLEDGMENTS}

Financial support was provided for this project by the American Jersey Cattle Club Research Foundation (Reynoldsburg, OH).

\section{REFERENCES}

Auldist, M. J., M. F. S. Pyman, C. Grainger, and K. L. Macmillan. 2007. Comparative reproductive performance and early lactation productivity of Jersey $\times$ Holstein cows in predominantly Holstein herds in a pasture-based dairying system. J. Dairy Sci. 90:48564862 .

de Vries, A., C. Steenholdt, and C. A. Risco. 2005. Pregnancy rates and milk production in natural service and artificially inseminated dairy herds in Florida and Georgia. J. Dairy Sci. 88:948-956.

Freyer, G., S. König, B. Fischer, U. Bergfeld, and B. G. Cassell. 2008. Invited review: Crossbreeding in dairy cattle from a German perspective of the past and today. J. Dairy Sci. 91:3725-3743.

Hare, E., H. D. Norman, and J. R. Wright. 2006. Survival rates and productive herd life of dairy cattle in the United States. J. Dairy Sci. 89:3713-3720.

Heins, B. J., L. B. Hansen, A. R. Hazel, A. J. Seykora, D. G. Johnson, and J. G. Linn. 2011. Short communication: Jersey $\times$ Holstein crossbreds compared with pure Holsteins for production, mastitis, and body measurements during the first 3 lactations. J. Dairy Sci. 94:501-506. 
Heins, B. J., L. B. Hansen, A. J. Seykora, D. G. Johnson, J. G. Linn, J. E. Romano, and A. R. Hazel. 2008. Crossbreds of Jersey $\times$ Holstein compared with pure Holsteins for production, fertility, and body and udder measurements during first lactation. J. Dairy Sci. 91:1270-1278.

Littell, R. C., P. R. Henry, and C. B. Ammerman. 1998. Statistical analysis of repeated measures data using SAS procedures. J. Anim. Sci. 76:1216-1231.

Lopez-Villalobos, N., D. J. Garrick, C. W. Holmes, H. T. Blair, and R. J. Spelman. 2000. Profitabilities of some mating systems for dairy herds in New Zealand. J. Dairy Sci. 83:144-153.

Minnesota DHIA. 2007. 2006 Annual summary data. Breed averages for 2006. Accessed Feb. 1, 2010. http://www.mndhia.org/annualsummary/summarydata.html.

Norman, H. D., J. R. Wright, S. M. Hubbard, R. H. Miller, and J. L. Hutchison. 2009. Reproductive status of Holstein and Jersey cows in the United States. J. Dairy Sci. 92:3517-3528.

Oseni, S., I. Misztal, S. Tsuruta, and R. Rekaya. 2003. Seasonality of days open in US Holsteins. J. Dairy Sci. 86:3718-3725.

Prendiville, R., E. Lewis, K. M. Pierce, and F. Buckley. 2010. Comparative grazing behavior of lactating Holstein-Friesian, Jersey, and Jersey $\times$ Holstein-Friesian dairy cows and its association with intake capacity and production efficiency. J. Dairy Sci. 93:764-774.

Prendiville, R., K. M. Pierce, and F. Buckley. 2009. An evaluation of production efficiencies among lactating Holstein-Friesian, Jersey, and Jersey $\times$ Holstein-Friesian cows at pasture. J. Dairy Sci. 92:6176-6185.

Prendiville, R., K. M. Pierce, L. Delaby, and F. Buckley. 2011. Animal performance and production efficiencies of Holstein-Friesian, Jersey, and Jersey $\times$ Holstein-Friesian cows throughout lactation. Livest. Sci. 138:25-33.

Roche, J. R., N. C. Friggens, J. K. Kay, M. W. Fisher, K. J. Stafford, and D. P. Berry. 2009. Invited review: Body condition score and its association with dairy cow productivity, health, and welfare. J. Dairy Sci. 92:5769-5801.

SAS Institute. 2008. SAS/STAT Software, Release 9.2. SAS Inst. Inc., Cary, NC.

VanRaden, P. M., A. H. Sanders, M. E. Tooker, R. H. Miller, H. D. Norman, M. T. Kuhn, and G. R. Wiggans. 2004. Development of a national genetic evaluation for cow fertility. J. Dairy Sci. $87: 2285-2292$

Weigel, K. A., and K. A. Barlass. 2003. Results of a producer survey regarding crossbreeding on US dairy farms. J. Dairy Sci. $86: 4148-4154$

Wildman, E. E., G. M. Jones, P. E. Wagner, R. L. Boman, H. G. Troutt Jr., and T. N. Lesch. 1982. A dairy cow body condition scoring system and its relationship to selected production characteristics. J. Dairy Sci. 65:495-501. 